\title{
Faktor Faktor Yang Mempengaruhi Kinerja Pelatih Donie
}

\section{ABSTRAK}

Tuntutan perkembangan olahraga menjadi sebuah industri menjadikan olahraga memiliki dimensi yang sangat luas, tidak hanya sebagai sebuah aktifitas fisik semata, namun juga mampu menjadi sebuah bisnis yang di dalamnya banyak melibatkan orang yang saling berkompetisi.

Pelatih sebagai salah satu tokoh yang berperan dibalik keberhasilan seorang pemain, diharapkan dan dituntut untk memberikan prestasi yang terbaik, salah satunya tentunya prestasi dari atlet dan klub yang di binanya.

Untuk bisa menjadi pelatih yang memiliki prestasi dan berdaya saing tinggi tentu akan terlihat dari kinerja pelatih yang merupakan salah satu tolok ukur yang dijadikan dasar dan pedoman dalam melihat, menilai dan mengevaluasi baik pelatih, proses latihan maupun hasil atau prestasi yang diperoleh dari proses latihan tersebut.

Banyak sekali faktor faktor yang mempengaruhi kecerdasan pelatih baik yang datang dari dalam diri (internal) ataupun yang berasal dari luar diri (eksternal) pelatih tersebut. Faktor faktor tersebut harus bisa dikelola dan dikembangkan oleh pelatih untuk bisa berkembang menjadi seorang pelatih yang baik yaitu pelatih yang memilki kinerja yang baik pula tentunya.

Dalam tulisan ini penulis ingin mengupas beberapa faktor yang cukup dominan yang mempengaruhi kinerja pelatih, diantaranya adalah:

1. Kecerdasan emosional

2. Gaya kepemimpinan

3. Moivasi dan

4. Kompetensi diri 
Kata Kunci: Kinerja Pelatih, Kecerdasan Emosional, Gaya Kepemimpin, Motivasi dan Kompetensi Diri

\section{A. Pendahuluan}

Pelatih adalah salah satu tokoh yang sangat berperan dalam melahirkan atlet-atlet hebat kelas dunia seperti : Roger Federer di cabang olahraga tenis, Michael Jordan pada cabang bolabasket, Tiger Wood di golf, dan Taufik Hidayat di bulutangkis dan lain sebagainya. Semua atletatlet kelas dunia tersebut merupakan atlet-atlet terbaik pada cabang olahraga mereka masing masing, yang mampu memberikan kebanggaan baik secara individu maupun kebanggaan sebuah negara.

Keberhasilan pelatih merupakan cerminan dari kinerja pelatih dalam kesehariannya baik di dalam maupun di luar lapangan. Ini jugalah yang menuntut pelatih harus senantiasa meningkatkan kompetensi diri yang tidak hanya diperoleh secara empiris melalui pengalaman di lapangan, namun yang tak kalah pentingnya adalah dengan membuka diri untuk selalu meng up date berbagai informasi dan pengetahuan pengetahuan, termasuk penemuan-penemuan penting yang mendukung kepelatihan olahraga moderen.

Pelatih harus secara teratur menyesuaikan diri dengan perkembangan terbaru, mampu mengubah atau memodifikasi praktek kepelatihannya. Perubahan semacam ini dapat terjadi apabila pelatih tersebut: (1) memiliki pemahaman atas prinsip-prinsip yang mapan dalam setiap ilmu yang relevan, (2) dengan teratur mencari pengetahuan baru 
dalam ilmu olahraga. Pelatih tidak perlu menjadi ilmuwan yang sesungguhnya tetapi untuk menjadi profesional, ia harus menjadi konsumen aktif berbagai informasi ilmiah yang mendukung cabang olahraganya dan sekaligus menerapkannya di lapangan.

Pelatih adalah seorang profesional yang tugasnya membantu atlet dan tim olahraga dalam memperbaiki dan meningkatkan penampilannya. Karena pelatih merupakan suatu profesi maka pelatih diharapkan dapat memberikan pelayanan sesuai dengan standar profesional yang ada. Pelatih adalah seorang profesional yang membantu atletnya mengembangkan kompetensinya sehingga atlet tersebut memiliki kemampuan dan kemauan yang tercermin dari prestasi atlet serta perilaku keseharian atlet dalam kehidupan sehari-harinya. Hal ini jugalah yag menjadikan tugas pelatih tidak hanya berkaitan dengan penguasaan keterampilan semata, namun juga berkaitan dengan aspek lainnya baik kognitif, afektif dan sosial. Hal ini senada dengan apa yang diungkapkan Harsono (1998) "Tugas pelatih adalah lebih luas dari sekedar di lapangan. Dia juga adalah seorang guru, pendidik, bapak, teman sejati".

Selanjutnya dilihat dari standar kompetensi pada Sistem Keolahragaan Nasional, terkait dengan kinerja lebih rinci dijelaskan dalam Peraturan Pemerintah Nomor 16 tentang Penyelengaraan Keolahragaan Pasal 87 bahwa; Standar kompetensi tenaga keolahragaan mencakup persyaratan:

a. pendidikan;

b. penataran/pelatihan; 
c. pengalaman;

d. unjuk kinerja; dan

e. kelayakan fisik dan mental sesuai dengan ketentuan

Unjuk kerja yang dimaksud tentunya tidak hanya prestasi yang ditorehkan oleh atlet atau anak didiknya namun juga adalah unjuk kerja yang tercermin dari bagaimana seorang pelatih dalam mengelola sebuah latihan mulai dari perencanaan, pengaplikasian dengan mengkolaborasikan unsur-unsur yang menunjang pencapaian prestasi, sampai nantinya bagaimana pelatih tersebut bisa mengevaluasi baik perencanaan yang disusun, maupun pelaksanaan latihan tersebut di lapangan, apakah sesuai dengan yang diharapkan atau ditemui kendalakendala yang membutuhkan solusi jalan keluar yang tepat.

Terkait dengan kinerja atau performance banyak para ahli yang telah membuat pengertian yang beragam, namun menurut Abdul dan Lintje (2009) menyimpulkan beberapa pendapat ahli terkait dengan pengertian kinerja yaitu:

1. Kinerja adalah prestasi atas tugas-tugas yang diberikan kepada pekerja atau menejer;

2. Kinerja merupakan hasil yag dicapai atas kegiatan yang dilakukan selama waktu tertentu;

3. Kinerja merupakan kemampuan organisasi untuk mencapai tujuannya dengan menggunakan sumber daya secara efisien dan efektif;

Dari pengertian ini dikaitkan dengan keberhasilan seorang pelatih, salah satunya dilihat dari kinerja pelatih termasuk didalamnya bagaimana pelatih itu sendiri sebagai pemimpin dari atlet yang merupakan sebagai sub sistem dari sebuah organisasi. Dari pengertian 
di atas dapat disimpulkan bahwa kinerja pelatih adalah kemampuan yang ditunjukkan oleh pelatih dalam melaksanakan tugas, pekerjaan dan tanggungjawab yang diberikan kepadanya. Kinerja pelatih merupakan penampilan atau performa yang mengacu kepada perbuatan dan tindakan pelatih dalam melatih dimana tindakan tersebut dapat diamati sebagai perwujudan dari kompetensinya. Untuk itu kinerja pelatih sangat ditentukan oleh penampilan dari pelatih tersebut dalam melaksanakan tugas utama sebagai seorang pelatih yang meliputi kemampuan dalam merencanakan, melaksanakan dan mengevaluasi latihan untuk mencapai target atau sasaran yang diinginkan khususnya upaya-upaya pencapaian prestasi atlet yang optimal.

Beratnya tuntutan dan harapan yang disandarkan kepada seorang pelatih dalam pencapaian prestasi, apalagi jika dikaitkan dengan tuntutan industri olahraga telah menempatan posisi pelatih dalam satu posisi strategis dan sekaligus merupakan posisi yang rawan. Penggantian dan pemecatan pelatih pada klub-klub kaya, cemooh penonton, tekanan dari beberapa atlet, tuntutan dari fans fanatik sebuah klub yang selalu mengiginkan kemenangan menjadikan posisi pelatih menjadi posisi yang penuh dengan tekanan. Pelatih tidak hanya dituntut cerdas dalam menentukan taktik dan strategi dalam sebuah pertandingan, atau cerdas dalam menganalisa jalannya sebuah pertandingan dan kemudian memberikan solusi dalam penentuan stretegi, pemilihan pemain dan lain sebagainya, yang kesemuanya 
seperti diibaratkan sebagai sebuah pertaruhan yang jika berhasil menang tidak menimbulkan masalah, namun jika gagal atau mengalami kekalahan sering ini dijadikan alasan untuk mengkritik, untuk menghujat bahkan untuk menjatuhkan sang pelatih.

Dibutuhkan kematangan yang tercermin dari kestabilan emosi yang saat untuk bisa dan mampu bertahan dari semua tekan mental yang harus ditanggung oleh banyak pelatih. Kematangan dalam mengelola emosi akan tercermin dari sikap pelatih saat menghadapi tekanan-tekanan yang datang namun tetap memperlihatkan sikap yang tenang dan mampu mencarikan solusi dari permasalahan yang ada. Kematangan emosi tersebut saat ini lebih dikenal dengan nama Kecerdasan emosi dimana dalam artian sempit mampu mengontrol emosi sehingga bisa menekan dan bahkan menghilangkan emosi yang bersifat negatif dan mengembangkan emosi yang bisa memberikan halhal positif dalam pencapaian peningkatan perestasi dan kinerja pelatih di lapangan.

Kecerdasan emosional ini menjadi penting khususnya terhadap kinerja pelatih baik di alam dan di luar lapangan terkait bagaimana pelatih tersebut mampu mengendalikan diri dari berbagai tekanan, himpitan dan permasalahan. Kemudian bagaimana pelatih tersebut bisa memotivasi atlet dan diri sendiri dalam suasana keseharian yang cenderung sering terperangkap oleh rutinitas latihan yang monoton dan menjaga intensitas motivasi diri agar selalu bergairah untuk bekerja 
dalam mengejar prestasi. Kemampuan merasakan apa yang dirasakan oleh orang lain termasuk berempati terhadap atlet dan yang tak kalah pentingnya adalah bagaimana pelatih tersebut berinteraksi dengan lingkungan dan orang lain disekitarnya. Hal ini merupakan konsekuansi dari tuntutan pelatih sebagai individu yang juga sebagai anggota keluarga dan bagian dari masyarakat.

Beratnya tekanan yang dialami oleh para pelatih, bahkan terkadang mereka dihadapkan pada situasi yang boleh dikatakan kurang manusiawi dikarenakan jam kerja yang terlalu panjang yang bahkan mengorbankan kehidupan pribadi dan keluarga, penghasilan yang kurang atau belum memadai, jenjang karir pekerjaan yang belum ada kepastian yang jelas yang kesemuanya memberikan tekanan lain dalam diri seorang pelatih.

Beberapa kasus yang sering terjadi terkait dengan ketidakmampuan dalam mengelola emosi secara baik dan benar diantaranya adalah; kasus pelemparan sepatu oleh Farguson kepada David Beckham, pemukulan pelatih kepada wasit bahkan yang lebih tragis lagi adalah ada pelatih yang sampai bunuh diri (Garry Speed) karena tidak kuat menghadapi beratnya tekanan.

Salah satu tugas utama dari pelatih adalah pemimpin bagi para atletnya, menurut Ayu dan Agus S. (2008) Kepemimpinan adalah suatu "proses dimana seseorang dapat menjadi pemimpin (leader) melalui aktivitas yang terus menerus sehingga dapat mempengaruhi yang 
dipimpinnya dalam rangka untuk mencapai tujuan organisasi”. Bagi pelatih yang memimpin para atlet baik di luar dan di dalam lapangan harus senantiasa mampu untuk terus membawa atletnya sesuai dengan tujuan yang diharapkannya. Keberhasilan pelatih dalam mencapai tujuan tersebut sangat dipengaruhi oleh gaya kepemimpinan yang merupakan model kepemimpinan dalam mempengaruhi kelompoknya khususnya para atlet untuk mencapai prestasi yang diharapkan. Gaya kepemimpinan ini akan sangat membantu pelatih dalam merealisasikan program yang disusun karena akan berpengaruh besar kepada diri atlet yang dipengaruhinya untuk berbuat, berjalan, bertindak dan berlatih sesuai dengan yang diharapkan pelatih tersebut. Dibutuhkan pengetahuan berupa ilmu dan seni dalam merealisasikan kepemimpinan tersebut dalam bentuk gaya atau tipe kepemimpinan yang efektif dalam mewujudkan prestasi yang diharapkan

Sebagai profesi yang memancarkan rasa hormat, hasil finasial yang diharapkan tentu bukanlah tujuan segala-galanya. Dibutuhkan pribadi yang kuat, dedikasi dan pengabdian serta menghayati profesi pelatih sebagai salah satu tugas mulia dalam membawa atletnya ke arah yang lebih baik lagi khususnya dalam menumbuhkan perilaku-perilaku positif seperti disiplin, ulet dan pantang menyerah, kerja sama dan lain sebagainya.

Sebagai bagian dari tuntutan zaman dan perkembangan teknologi pelatih telah berkembang menjadi sebuah profesi yang 
menuntut berbagai persyaratan dan kompetensi agar produk jasa yang ditawarkan bisa memberikan imbalan yang memadai. Keberhasilan pelatih yang salah satu indikatornya adalah prestasi dari si atlet yang di asuhnya, juga berpengaruh terhadap nilai jual si pelatih yang juga berkontribusi terhadap kesejahteraan pelatih. Sebaliknya dengan kesejahteraan yang baik tentunya pelatih bisa fokus dalam melatih, merancanakan dan melaksanakan program serta target-target yang diberikan dan tentunya prestasi yang diharapkan bisa diwujudkan.

Dalam mkalah ini akan dibahas beberapa faktor yang mempengaruhi kinerja pelatih tersebut diantaranya adalah kecerdasan emosional dimana dibutuhkan kemampuan pelatih dalam mengelola emosi agar dalam menjalankan tugas dan tanggungjawab tersebut mampu menampilkan emosi emosi yang positif yang bisa menunjang dalam pelaksanaan keseharian di lapangan. Gaya kepemimpinan pelatih yang merupakan salah satu cara pelatih dalam mempengaruhi, mengajak dan membawa para atlet binaanya melalui pendekatan kepemimpinan yang sesuai dengan kebutuhan situasi dan kondisi yang ada pada saat tersebut. Selanjutnya sebagai manusia dengan berbagai keinginan dan kebutuhannya, dibutuhkan motivasi kuat yang memuat pekerjaan atau profesi pelatih tidak saja dilihat dari sisi finansial, namun juga ada motivasi lain yang menjadikan pekerjaan ini terus menarik, menantang dan memilik daya tarik untk dijalani. Kemudian yang tidak kalah pentingnya adalah kompetensi diri yang meliputi tidak hanya 
pengetahuan tetapi juga keterampilan yang harus ada dan dimiliki oleh pelatih sebagai pra syarat untuk menjadi pelatih dengan berbagai peran yang ada pada dirinya.

B. Pembahasan

1. Kinerja Pelatih

Kebutuhan yang paling penting dalam mengembangkan atlet pada level yang lebih baik adalah ketersediaan pelatih yang handal dan baik. Kita menyadari bahwa pembinaan prestasi atet sangat membutuhkan pelatih yang memiliki pengetahuan, motivasi, intens, peka terhadap kebutuhan individu, dan sukses dalam memecahkan masalah, suasana latihan yang mampu mendukung pencapaian prestasi atlet. Sebaliknya Jika pelatih memiliki pengetahuan teknis atau teoritis yang buruk, kurang pengalaman, tidak mampu untuk merencanakan program yang komprehensif, atau memiliki motivasi, atau tidak bisa mengelola waktu dengan sebaik baiknya akan berdampak kurang baik terhadap perkembangan prestasi dari atlet yang dibinannya .

Hal ini merupakan kesulitan dan tantangan di negara berkembang untuk menciptakan sebuah sistem untuk mengembangkan pelatih handal atau level tinggi . Tantangan ini harus dicarikan solusi agar pelatih bisa meningkatkan diri sesuai dengan kebutuhan dan fungsi sebagai seorang pelatih yang dibutuhkan oleh para atlet berprestasi

Dikaitkan dengan beberapa pengertian tentang kinerja di atas, kinerja pelatih bisa diartikan sebagai hasil atau outcome dari seseoarang 
dalam hal ini pelatih dalam menjalankan peran, tugas dan fungsinya sebagai seorang pelatih. Sebagai salah satu orang yang sangat berperan dalam membawa dan membimbing para atlet bimbingannya khususnya dalam peningkatan prestasi olahraga kecabangannya tuntutan dan peran dan fungsi pelatih menjadi sangat penting..

Fungsi dan peran seorang pelatih sangat erat hubungannya dengan capaian prestasi yang diukir oleh atlet. Pelatih adalah seorang yang harus tahu tentang semua kebutuhan yang menjadi dasar bagi terpenuhinya kondisi dimana atlet memiliki peluang untuk mencapai prestasi. Hubungan antara pelatih atlet yang dibina harus merupakan hubungan yang mencerminkan kebersamaan pandangan dalam mewujudkan apa yang dicita-citakan.

Seorang pelatih dituntut mampu menjalani profesinya dan tidak semata-mata bermodalkan dirinya sebagai mantan atlet, melainkan harus melengkapi dirinya dengan seperangkat kompetensi pendukung yang penting, diantaranya adalah kemampuan untuk mentransfer pengetahuan keolahragaannya kepada atlet secara lengkap baik dari segi teknik, taktik, maupun mental. Kemampuan untuk mengorganisir dinamika mental atlet merupakan hal yang sangat penting untuk dikuasai pelatih. Kompetensi ini akan lebih banyak terlihat ketika pelatih menghadapi suasana kompetensi yang penuh dengan tekanan. Pengalaman menjadi modal utama dalam menghadapi situasi ini. 
Penguasaan kecabangan olahraga dan dalamnya pengalaman tidak serta-merta akan menjadikan dirinya sebagai pelatih yang dihormati dan disegani kecuali jika dirinya sudah memiliki karakter dan filosofi sebagai seorang pelatih. Karakter adalah konsistensi sikap dan cara pandang dalam menghadapi suatu masalah. Sedangkan filosofi adalah bingkai kepribadian yang akan menjadi jembatan bagi aktualisasi seluruh komponen yang dimiliki agar apa yang dilakukan dapat diterima oleh orang lain.

Dengan memiliki filosofi seorang melatih akan dapat memiliki pegangan ketika menjalankan tugas profesionalnya. Menyadari pentingnya pengembangan kompetensi pelatih sehingga dalam Undang Undang Sistem Keolahragaan Nasional ditegaskan tentang standar kompetensi (pasal 81). Standar komptetensi dimaksud adalah standar nasional yang berkaitan dengan kemampuan minimal yang mencakup pengetahuan, sikap, dan keterampilan yang harus dimiliki seseorang untuk dapat dinyatakan lulus dalam uji kompetensi. Dalam hal ini kompetensi pelatih diartikan juga harus di dasarkan pada pengetahuan sebagai pelatih, sikap sebagai pelatih, dan keterampilan sebagai pelatih.

Pengetahuan yang harus dimiliki pelatih termasuk didalamnya wawasan yang luas terkait dengan disiplin ilmu yang dimiliki yang mendukung pelatih dalam melaksanakan tugas kepelatihannya. Pengetahuan dimaksud meliputi pengetahuan tentang ilmu fisiologi olahraga, ilmu melatih, ilmu psikologi, giszi dan lain sebagainya yang 
kesemuannya dibutuhkan dan harus senantiasa di up date oleh para pelatih dalam menjalankan tugas dan perannya sebagai seorang pelatih.

Sikap pelatih dalam hal ini termasuk didalamnya etika dan estetika dari pelatih. Etika dalam artian pelatih harus mencerminkan nilai-nilai yaang baik yang dijabarkan dalam aturan dan ketentuan serta perbuatan kesehariannya dan harus mencerminkan nilai nilai yang luhur seperti, disiplin, sopan santun, sportifitas dan lain sebagainya. Sedangkan estetika bahwa dalam kesehariannya pelatih harus bisa mencerminkan keindahan, kebersihan dan ketertiban baik dalam pengelolaan latihan maupun dalam bertutur kata dalam berkomunikasi

Pelatih yang baik tentunya adalah pelatih yang memiliki keinginan dan kemampuan untuk berkembangn baik secara pengetahuan dan keterampilan ke arah yang lebih baik lagi. Pelatih yang handal harus memiliki atribut sebagai pelatih berkinerja tinggi diantaranya yaitu:

1. Standar pengetahuan yang diperlukan

2. Bersedia untuk melakukan pekerjaan yang diperlukan

3. Tidak ada kompromi ... bergairah

4. Mampu meyakinkan atlet untuk mengikuti aturan dan perintahnya

5. Terorganisir ... fokus

6. Pemecah masalah ... praktis ... mencarikan jalan keluar

7. Menguasai olahraga

8. Mempertahankan kontrol secara keseluruhan 
9. Percaya diri dalam bertindak

10. Berpengalaman dalam taktik (IOC: 2001)

Dari kesepuluh atribut pelatih berkinerja tinggi tersebut dapat disimpulkan bahwa pelatih harus memilki pengetahuan dan keterampilan kecabangan, pribadi yang kuat untuk memimpin dan mengendalikan latihan dan atlet, serta kesadaran diri dan tanggung jawab untuk senantiasa mengembagkan diri demi peningkatan prestasi atlet.

Secara ringkas dari berbagai aspek tersebut terkait dengan peran dan tugas pelatih Tahir Djide dalam Harsuki (2003) menyebutkan:

a. Cermat menentukan sasaran atau tujuan latihan

b. Menetapkan tujuan latihan yang bersifat realitik

c. Memilih metode, model model, yang cocok untuk memenuhi kebutuhan setiap pemain

d. Memotivasi pemain untuk berlatih keras

e. Mencermati latihan pemanasan (warm up ) dan pencegahan cidera (avoid Injury)

f. Istirahat dan minum yang cukup

g. Memanfaatkan aspek pembinaan psikologis

h. Cermat dan terampil melakukan seni berkomunikasi

Tugas dan peran inilah yang harus dipahami dan dijalankan oleh pelatih dalam upaya mewujudkan kinerja pelatih tersebut di lapangan. Hal ini jugalah yang menuntut pelatih harus senantiasa berupaya meningkatkan kemampuan kinerja dan kompetensi diri guna mewujudkan tugas dan peran sebagai seorang pelatih yang baik 


\section{Kecerdasan Emosional}

Dalam satu kurun waktu paradigma tentang kecerdasan mengalami suatu lompatan defenisi yang luar biasa. Dulunya kecerdasan sangat identik dengan IQ atau kecerdasan akal, sehingga semua persoalan selalu dikaitkan dengan IQ seseorang. IQ pada saat itu dianggap sebagai salah satu faktor yang sangat menentukan kesusksesa seoarag dalam berbagai bidang.

Namun kenyataan di lapangan membuktikan bahwa orang yang memiliki kecerdasan otak saja, atau banyak memiliki gelar yang tinggi belum tentu sukses berkiprah di dunia pekerjaan. Banyak tokoh sukses tidak berasal dari orang yang berpendidikan formal tinggi. Hal ini salah satunya disebabkan karena kebanyakan program pendidikan hanya berpusat pada kecerdasan akal (IQ) saja, padahal lebih jauh yang tak kalah pentingnya adalah bagaimana mengembangkan kecerdasan lain, seperti ketangguhan, inisiatif, optimisme, kemampuan beradaptasi yang hal ini ternyata sangat dibutuhkan untuk berkomunikasia dan beradaptasi dalam lingkungan pekerjaan.

Hasil survey yang dilakukan di Amerika Serikat tentang kecerdasan emosional menjelaskan bahwa apa yang diinginkan oleh pemberi kerja tidak hanya keterampilan teknik saja melainkan dibutuhkan kemampuan dasar untuk belajar dalam pekerjaan yang bersangkutan. Di antaranya, adalah kemampuan mendengarkan dan berkomunikasi lisan, adaptasi, 
kreatifitas, ketahanan mental terhadap kegagalan, kepercayaan diri, motivasi, kerjasama tim dan keinginan memberi kontribusi terhadap perusahaan. Seseorang yang memiliki kecerdasan emosional yang tinggi akan mampu mengendalikan emosinya sehingga dapat menghasilkan optimalisasi pada fungsi kerjanya.

Goleman (2003) menyatakan bahwa kemampuan akademik bawaan, nilai rapor, dan prediksi kelulusan pendidikan tinggi tidak memprediksi seberapa baik kinerja seseorang sudah bekerja atau seberapa tinggi sukses yang dicapainya dalam hidup. Sebaliknya ia menyatakan bahwa seperangkat kecakapan khusus seperti empati, disiplin diri, dan inisiatif mampu membedakan orang sukses dari mereka yang berprestasi biasa-biasa saja, disamping kecerdasan akal yang dapat mempengaruhi keberhasilan orang dalam bekerja. la juga tidak mempertentangkan kecerdasan intelektual dan kecerdasan emosional, melainkan memperlihatkan adanya kecerdasan yang bersifat emosional, ia berusaha menemukan keseimbangan cerdas antara emosi dan akal. Kecerdasan emosional menentukan seberapa baik seseorang menggunakan keterampilan-keterampilan yang dimilikinya, termasuk keterampilan intelektual.

Pengertian kecerdasan emosional menurut Goleman (2000) adalah kemampuan merasakan, memahami, dan secara efektif menerapkan daya dan kepekaan emosi sebagai sumber energi, informasi, koneksi, dan pengaruh yang manusiawi. Menurut Salovey dan Mayer 
dalam Stein (2002), kecerdasan emosional adalah kemampuan untuk mengenali perasaan, meraih dan membangkitkan perasaan untuk membantu pikiran, memahami perasaan dan maknanya, dan mengendalikan perasaan secara mendalam sehingga membantu perkembangan emosi dan intelektual. Secara sederhana Wibowo (2002) mendefinisiskan kecerdasan emosional adalah kecerdasan untuk menggunakan emosi sesuai dengan keinginan, kemampuan untuk mengendalikan emosi sehingga memberikan dampak yang positif.

Pendapat dari Wibowo tersebut walaupun dibuat dengan ringkas namun memiliki makna yang mendalam terkait dengan bagaimana menggunakan, mengelola dan mengendalikan emosi secara cerdas agar memberikan dampak positif kepada seseorang. Kecerdasan ini pada akhirnya adalah mampu menempatkan sesuatu dengan benar, empati atau kepekaan diri terhadap orang lain serta mampu bertindak dan bersikap yang bisa diterima oleh diri dan orang lain.

Menurut Goleman (2000) terdapat lima dimensi atau komponen kecerdasan emosional (EQ) yang keseluruhannya diturunkan menjadi lima kompetensi. Kelima dimensi atau komponen tersebut adalah:

1. Pengenalan diri (Self awareness), artinya mengetahui keadaan dalam diri, hal yang lebih disukai, dan intuisi. Kompetensi dalam dimensi pertama adalah mengenali emosi sendiri, mengetahui kekuatan dan keterbatasan diri, dan keyakinan akan diri sendiri.

2. Pengendalian diri (self regulation), artinya mengelola keadaan dalam diri dan sumber daya diri sendiri. Kompetensi dimensi kedua ini adalah menahan emosi dan dorongan 
negatif, menjaga norma kejujuran dan integritas, bertanggung jawab atas kinerja pribadi, luwes terhadap perubahan, dan terbuka terhadap ide-ide serta informasi baru.

3. Motivasi (motivation), artinya dorongan yang membimbing atau membantu peraihan sasaran atau tujuan. Kompetensi dimensi ketiga adalah dorongan untuk menjadi lebih baik, menyesuaikan dengan sasaran kelompok atau organisasi, kesiapan untuk memanfaatkan kesempatan, dan kegigihan dalam memperjuangkan kegagalan dan hambatan.

4. Empati (empathy), yaitu kesadaran akan perasaan, kepentingan, dan keprihatinan orang. Dimensi keempat terdiri dari kompetensi understanding others, developing others, customer service, menciptakan kesempatankesempatan melalui pergaulan dengan berbagai macam orang, membaca hubungan antara keadaan emosi dan kekuatan hubungan suatu kelompok.

5. Keterampilan sosial (social skills), artinya kemahiran dalam menggugah tanggapan yang dikehendaki oleh orang lain. Diantaranya adalah kemampuan persuasi, mendengar dengan terbuka dan memberi pesan yang jelas, kemampuan menyelesaikan pendapat, semangat leadership, kolaborasi dan kooperasi, serta team building.

\section{Gaya kepemimpinan}

Gaya Kepemimpinan adalah cara yang digunakan oleh seorang pemimpin dalam mempengaruhi bawahannya (followers) agar mau melaksanakan tugas dan kewajiban sesuai dengan yang diharapkan untuk mencapai tujuan yang telah ditentukan sebelumnya. Gaya kepemimpinan menurut Stoner (1994) adalah berbagai pola tingkahlaku yang disukai oleh pemimpin dalam mengarahkan dan mempengaruhi bawahannya. 
Selanjutnya dikatakan efektifitas pemimpin juga dipengaruhi oleh berbagai faktor

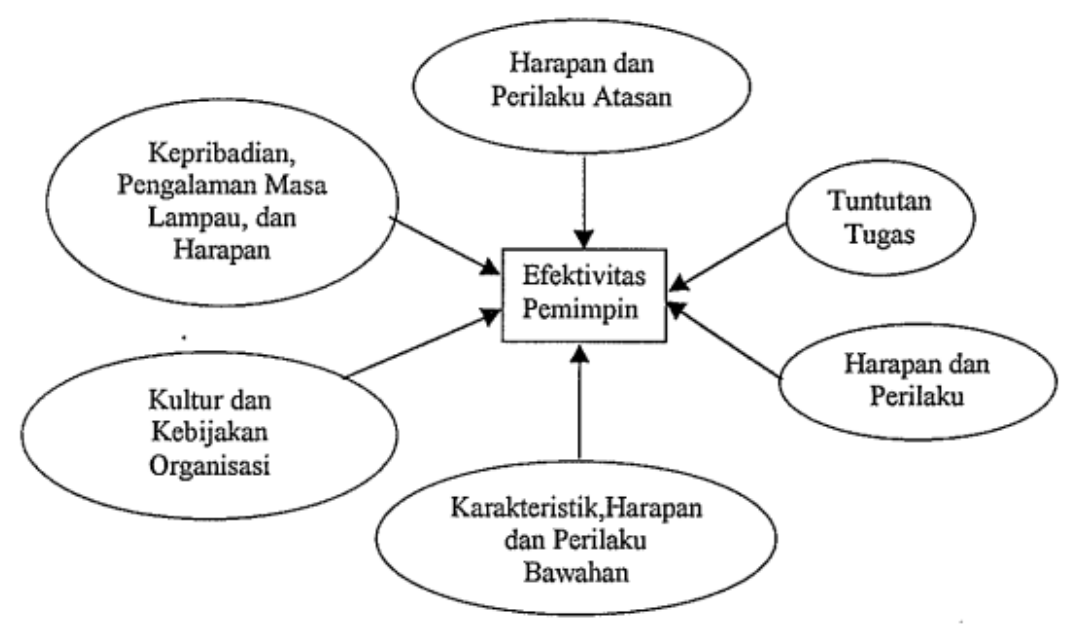

Gambar 2.1 . Faktor Kepribadian dan situasional yang mempengaruhi

Kepemimpinan Efektif (Stoner: 1994)

Keterangan:

1. Kepribadian, pengalaman masa lalu, dan harapan pemimpin: hal ini dapat mempengaruhi pemimpin dalam memilih gaya kepemimpinannya sebagai contoh seorang menejer yang telah melaksanakan supervisi kecil, mungkin memilih gaya kepemimpinan yang berorientasi pada karyawan;

2. Harapan dan perilaku atasan: karena memiliki kekuasaan untuk menyalurkan imbalan organisasional seperti bonus dan promosi, para atasan tentu saja mempengaruhi manajer tingkat bawah.

3. Tuntuan tugas: sifat dan tanggung jawab pekerjaan bawahan juga akan mempengaruhi gaya kepemimpinan yang akan dipilih oleh seorang menejer.

4. Harapan dan perilaku rekan : Pandangan dan perilaku rekan menejer sering sangat efektif mempengaruhi kerja menejer. 
5. Karakteristik harapan dan perilaku bawahan keterampilan, pelatihan dan sikap bawahan mempengaruhi gaya kepempinan yang dipilih oleh menejer

6. Kultur kebijakan operasional: keduanya membentuk perilaku pemimpin dan harapan bawahannya

Gaya kepemimpinan adalah cara-cara khas yang digunakan atau dilaksanakan oleh seseorang dalam rangka menjalankan kepemimpinannya. Masing-masing pemimpin dapat memiliki gaya yang berbeda. Menurut Wahjosumidjo (1993), gaya kepemimpinan adalah sebagai berikut:

1. Gaya kepemimpinan yang berorientasi tugas:

a. Pemimpin selalu memberikan petunjuk-petunjuk kepada orang yang Dipimpin.

b. Pemimpin selalu mengadakan pengawasan secara ketat terhadap orang yang dipimpin.

c. Pemimpin meyakinkan kepada orang yang dipimpin bahwa tugas-tugas harus dapat dilaksanakan sesuai dengan keinginan pemimpin

2. Gaya kepemimpinan yang berorientasi kepada orang yang dipimpin:

a. Pemimpin lebih memberikan motivasi daripada mengadakan

b. pengawasan terhadap orang yang dipimpin.

c. Pemimpin melibatkan orang yang dipimpin dalam mengambil

d. Keputusan

e. Pemimpin lebih bersikap penuh kekeluargaan, percaya, hubungan 
kerjasama yang saling menghormati diantara sesama anggota kelompok

Kedua gaya kepemimpinan tersebut menempatkan posisi strategis dari pemimpin yang menitikberatkan kepada sikap pemimpin tesebut dalam mempengaruhi bawahannya untuk mencapai tujuan yang diinginkan. Mengenai ukuran-ukuran gaya kepemimpinan, Fiedler dalam Siagian (2003) mendefinisikan atas dasar tiga orientasi yang dapat diukur, yaitu:

1. Position power (kekuasaan posisi); kemampuan untuk mencapai produktifitas yang tinggi melalui kerja sama.

2. Task structure (struktur tugas); suatu gaya yang mengutamakan adanya kehendak atau keinginan untuk senantiasa menyelesaikan tugas atau pekerjaannya.

3. Leader member relations (hubungan pemimpin dengan bawahan); suatu gaya yang menunjukkan perhatian yang mengutamakan hubungan dengan faktor manusia.

Orientasi ini memberikan gambaran yang lebih jelas tentang indikator-indikator dari maing masing gaya kepemimpinan tersebut untuk dapat diukur baik melalui posisi kekuasaan, struktur tugas ataupun hubungan antara pimpinan dan bawahan nantinya.

Selanjutnya Menurut Siagian (2004), terdapat tiga tipe pokok kepemimpinan, yaitu :

\section{a. Tipe Kepemimpinan Otoriter}

Tipe kepemimpinan ini menempatkan kekuasaaan ditangan satu orang. Kedudukan dan tugas anak buah semata-mata hanya sebagai pelaksana keputusan dan bahkan pelaksana kehendak 
pimpinan. Pimpinan memandang dirinya lebih dalam segala hal, dibandingkan dengan bawahannya.

b. Tipe Kepemimpinan Kendali Bebas

Tipe kepemimpinan ini merupakan kebalikan dari tipe kepemimpinan otoriter. Pemimpin berkedudukan sebagai simbol. Kepemimpinan dijalankan dengan memberikan kebebasan penuh pada orang yang dipimpin dalam mengambil keputusan dan melakukan kegiatan menurut kehendak dan kepentingan masing-masing, baik secara perorangan maupun kelompok-kelompok kecil. Pemimpin hanya memfungsikan dirinya sebagai penasihat.

c. Tipe Kepemimpinan Demokratif

Tipe kepemimpinan ini menempatkan manusia sebagai faktor utama dan terpenting dalam setiap kelompok atau organisasi. Pemimpin memandang dan menempatkan orang-orang yang dipimpinnya sebagai subjek yang memiliki kepribadian dengan berbagai aspeknya, seperti dirinya juga. Kemauan, kehendak, kemampuan, buah pikiran, kreativitas, pendapat, inisiatif yang berbeda-beda dan dihargai disalurkan secara wajar. Kepemimpinan demokratis adalah kepemimpinan yang aktif, dinamis, dan terarah. Kepemimpinan tipe ini dalam mengambil keputusan sangat mementingkan musyawarah, yang diwujudkan pada setiap jenjang dan di dalam unit masingmasing.

Ketiga gaya kepemimpinan tersebut masing masingnya memiliki kelebihan dan kekurangan masing masingnya. Tidak ada gaya kepemimpinan tersebut yang nyaris sempurna. Masalahnya sekarang adalah dibutuhkan pengalaman an kemampuan dari pada pelatih dalam memilih gaya kepemimpinan yang sesuai atau tepat dengan situasi dan kondisi yang ada. 
4. Moivasi

Untuk bisa bertahan hidup manusia di dorong untuk memenuhi kebutuhan hidupnya. Ada energi atau tenaga pendorong yang menyebabkan manusia mampu bergerak, melaksanakan aktivitas untuk bertahan hidup dan memenuhi semua kebutuhanya. Terkait dengan hal tersebut ( Maslow: 1994) mengatakan bahwa manusia adalah makhluk yang mempunyai keinginan dan jarang mencapai keadaan puas sepenuhnya kecuali untuk waktu yang singkat. Apabila keinginan yang satu telah terpenuhi, keinginan yang lainnyapun muncul menggantikan tempat keinginan yang pertama. Jika keinginan ini telah terpenuhi, masih ada keinginan lainnya yang akan tampil depan dan begitu seterusnya.

Energi pendorong tersebut dikenal dengan istilah motivasi. Istilah Motivasi berasal dari kata motif yang dapat diartikan sebagai kekuatan individu, yang menyebabkan individu tersebut bertindak atau berbuat (Uno: 2006:3). Terkait dengan pengertian motivasi sebelum melangkah ke pengertiannya, terlebih dahulu kita harus melihat dan menelaah antara kata motif dengan kata motivasi. Motif adalah tenaga penggerak dalam diri seseorang untuk melakukan aktifitas tertentu, demi mencapai tujuan tertentu (Winkel : 1986:151). Motif merupakan dasar yang kokoh untuk munculnya motivasi. Dengan demikian motivasi merupakan dorongan yang terdapat dalam diri seseorang untuk berusaha mengadakan perubahan tingkah laku yang lebih baik dalam memenuhi kebutuhanya. 
Dahama dan Bhatnagar dalam Setyobroto (1989) memandang motivasi sebagai proses yag menciptakan tindakan bertujuan dan disadari. Motif merupakan kumpulan perasaan perasaan, kesenangan kesenangan, kecenderungan dan dorongan insting yang menampakan sebagai minat, selama tidak ada sesuatu yang merintangi yang bersifat internal maupun eksternal, akan memimpin tindakan tindakannya untuk memenuhi minatnya.

Selanjutnya dengan membandingkan beberapa pendapat mengenai motif dan motivasi Setyoboto (1990) mengajukan sifat-sifat motif sebagai berikut:

1) Merupakan sumber penggerak dan pendorong dari dalam diri subjek yang terorganisir;

2) Terarah pada tujuan tertentu secara selektif;

3) Untuk mendapatkan kepuasan atau menghindari hal-hal yang tidak menyenangkan;

4) Dapat disadari atau tidak di sadari;

5) Ikut menentukan pola kegiatan;

6) Suatu tindakan dapat didorong oleh berbagai motif;

7) Bersifat dinamik, dapat berubah dan dapat dipengaruhi;

8) Mengubah ekspresi dari suatu emosi atau afeksi

9) Ada hubungan dengan unsur kognitif dan konatif.

10) Motivasi merupakan determinan sikap dan tindakan. 
Dengan membandingkan sifat-sifat motif tersebut dan dengan membandingkan berbagai pendapat mengenai motif dan motivasi Setyobroto menyimpulkan bahwa " motif adalah sumber penggerak dan pendorong yang bersifat dinamik, dapat dipengaruhi, merupakan determinan sikap dan pendorong suatu tindakan terarah pada tujuan tertentu untuk mendapatkan kepuasan atau menghidari hal hal yang tidak menyenangkan, baik disadari atau tidak disadari dan ada hubungannya denagan aspek kognitif, konatif dan afektif. Dan secara singkat dikatakan bahwa " motif adalah sumber penggerak dan pendorong tingkah laku individu memenuhi kebutuhan untuk mencapai tujuan tertentu.

Mengenai energi pendorong yang mempengaruhi motif, salah satu yang terkenal adalah teori yang dikemukanan oleh Maslow yang mengklasifikasikan energi pendorong tersebut ke dalam lima kebutuhan dasar manusia yang meliputi:

1) Kebutuhan- kebutuhan fisiologis

2) Kebutuhan akan keselamatan

3) Kebutuhan akan rasa memilki dan rasa cinta

4) Kebutuhan akan rasa harga diri dan

5) Kebutuhan akan perwujudan (aktualisasi) diri. ( Maslow 1994)

Kebutuhan fisiologis dijadikan dasar titik tolak kebutuhan teori motivasi Maslow. Kebutuhan ini merupakan kebutuhan yang paling kuat. 
Tegasnya pada diri manusia selalu merasa kurang dalam hidupnya, kebutuhan fisiologis merupakan motivasi terbesar. Seseorang yang kekurangan makanan, keamanan, kasih sayang dan penghargaan besar kemungkinan akan banyak membutuhkan makanan dari yang lainnya. Jika kebutuhan fisiologis kurang ini terpenuhi, maka organisme tersebut akan didominasi oleh kebutuhan pokok yang akhirnya kebutuhan yang lain tidak akan ada atau terdesak ke belakang.

Apabila kebutuhan fisiologis telah terpenuhi, maka akan muncul kebutuhan baru berikutnya yaitu kebutuhan akan keselamatan atau perlindungan yang meliputi diantaranya keamanan, kemantapan, ketergantungan, perlindungan, bebas dari rasa takut, cemas dan kekalutan, kebutuhan akan struktur, ketertiban, hukum, batas batas, kekuatan diri dan lain sebagai nya.dalam lingkungan sosial kebutuhan akan keselamatan hal yang sangat penting setiap kali mendapatkan ancaman terhadap hukum, ketertiban dan lainnya.

Kebutuhan berikutnya adalah kebutuhan akan rasa cinta, rasa kasih dan rasa memiliki. Manusia sangat merasakan bagaimana perasaan ketiadaan kawannan, kekasih, isteri anak dan haus akan hubungan kasih sayang dengan orang orang pada umumnya. Jika tidak terpenuhinya kebutuhan ini manusia akan merasakan perihnya rasa kesepian, pengucilan sosial, penolakan, tiada keramahan dan keadaan yang tiada menentu. 
Selanjutnya kebutuhan manusia adalah keinginan akan penilaian, rasa penghormatan, harga diri dan penghargaan dari orang lain. Kebutuhan ini dapat di kelompokan kepada: pertama keinginan untuk berprestasi, berkecukupan, memiliki keunggulan dan kemampuan, percaya diri. Kedua yang disebut dengan hasrat akan nama baik, gengsi, prestise (yang dirumuskan sebagai penghormatan dan penghargaan dari orang lain).

Terakhir adalah kebutuhan akan aktualisasi diri yaitu kecenderungan untuk mewujudkan diri sesuai dengan kemampuannya. Kecenderungan tersebut merupakan keinginan untuk makin lama makin baik atau istimewa, untuk menjadi apa saja yang sesuai dengan kemampuannya. Hal inilah yang nantinya kan menunjukan perilaku berbeda antara satu dengan yang lainnya, antara satu atlet dengan atlet lainnya karena kecenderungan mereka untuk menampilan semua potensi agar menjadi istimewa atau yang terbaik di bidangnya.

Di dalam proses pembinaan olahraga ada beberapa bentuk motivasi yang dapat dibedakan. Pertama adalah motiivasi secara umum, artinya motivasi sesorang untuk melibatkan diri di dalam suatu aktivitas tertentu dalam memperoleh hasil atau sasaran tertentu ( Morgan dkk dalam monthy: 2000). Yang kedua adalah motivasi untuk berprestasi (achievement motivation), yaitu orientasi seseorang untuk tetap berusaha memperoleh hasil terbaik semaksimal mungkin dengan dasar kemampuan untuk tetap bertahan sekalipun gagal, dan tetap berusaha menyelesaikan 
tugasnya dengan baik (Gil dalam Monthy:2000). Dari kedua motivasi tersebut dalam kontek dunia olahraga tidak bisa hanya motivasi dalam artian umum namun dominasi dari motivasi untuk berprestasi menjadikan olahraga menjadi sangat menarik dan membutuhkan tantangan tersendiri kepada seluruh pelaku pelaku yang terlibat, khususnya kepada atlet dan pelatih yang aktif terlibat di dalam proses latihan.

Selanjutnya Monthy merangkum beberapa pendapat pakar psikolgi seperti Anshel (1997, Duda 1993 dan Weinberg \& Gould 1995) menyimpulkan ada beberapa sumber dari motivasi sebagai berikut:

a) Orientasi pelaku (Trait Centered Orientation)

Orientasi ini mengemukan bahwa sumber motivasi terletak pada diri yang bersangkutan. Jadi motivasi merupakan bentuk kecenderungan pribadi atau "trait".

b) Orientasi Situasional Lingkungan (Situation Centered Orientation). Pandangan ini mengemukakan bahwa kecenderungan pribadi saja tidak cukup untuk memotivasi individu. Sebaliknya lingkunganlah yang memberikan peluang serta memupuk motivasi individu.

c) Orientasi Interaksional (Interactional orientation). Pandangan interaksional berpendapat bahwa motivasi terbentuk karena adanya kombinasi faktor pelaku (participant) dan faktor lingkungan (situasional).

Ketiga sumber inillah yang dijadikan sumber dari motivasi yag membuat seseorang untuk bertindak, berbuat khususnya dalam upaya pemenuhan kebutuhannya.

\section{Kompetensi diri}


Pelatih adalah orang penting di balik kesuksesan prestasi seorang atlet. Dibalik prestasi yang fenomenal, di balik atlet yang sukses, dibelakangnya pastilah berdiri seorang pelatih yang baik. Masih banyak pakar yang kebingungan dalam memberikan batasan tentang kompetensi, apakah kompetensi tersebut karakterik organisasi ataupun karakteristik kerja. Kesulitan dalam mendefinisikan atau merumuskan pengertian dari kompetensi dikarenakan bahwa kompetensi memiliki defenisi yang luas dan mencakup berbagai aspek.

The British National Council of vocational Qualifications merumuskan pengertian kompetensi sebagai kemampuan untuk melaksanakan kegiatan kegiatan kerja sesuai dengan standar yang diperlukan. Sedangkan menurut Australia's National Training Board mengatakan bawa kompetensi terdiri dari spesifikasi pengetahuan dan keterampilan serta penerapan pengetahiuan dan keterampilan tersebut pada standar kinerja yang dipersyaratkan.

Melihat luasnya pengertian yang tercakup dalam kompetensi Milkovic \& Newman dalam Rahmat (2009) mengelompokan kompetensi tersebut ke dalam 5 bidang yaitu:

1) Keterampilan

2) Pengetahuan

3) Konsep diri

4) Ciri 
5) Dan motif

Selajutnya terkait dengan pengertian kompetensi tersebut, Sedarmayanti, (2004) menyimpulkan beberapa pendapat ahli terkait dengan kompetensi yaitu:

1. Konsep luas, memuat kemampuan mentransfer keahlian dan kemampuan kepada situasi baru dalam wilayah kerja, menyangkut organisasi dan perencanaan pekerjaan, inovasi dan mengatasi aktivitas rutin, kualitas efektivitas personel yang dibutuhkan di tempat berkaitan deugan rekan kerja. Menejer serta pelanggan.

2. Kemampuan dan kemauan untuk melakukan tugas

3. Dimensi perilaku yang mempengaruhi kinerja .

4. Karakteristik individu apapun yang dapat dihitung dan diukur secara konsisten, dapat dibuktikan untuk membedakan secara signifikan antara kinerja yang efektif dengan yang tidak efektif.

5. Kemampuan dasar dan kualitas kinerja yang diperlukan untuk mengerjakan pekerjaan dengan baik.

6. Bakat, sifat dan keahlian individu apapun yang dapat dibuktikan. dapat dihubungkan dengan kinerja yang efektif dan baik sekali.

Berdasarkan uraian tersebut Sedarmayanti menyimpulkan secara menyeluruh bahwa kompetensi merupakan faktor mendasar yang perlu dimiliki seseoraug sehingga mempunyai kemampuan lebih dan membuatnya berbeda dengan seseorang yang mempunyai kemampuan rata-rata atau biasa saja.

\section{KESIMPULAN}


Menilai kinerja pelatih tidak hanya di lihat dari hasil pencapaian atau prestasi dari anak didik atau atlet yang dilatihnya, namun jika dilihat dari pada prestasi juga merupakan suatu proses. Dalam artian ini jika proses baik hasilnya bisa baik dan juga bisa tidak namun jika prosesnya salah mak hasilnya pasti tidak akan baik.

Banyak sekali fator-faktor yang mempengaruhi kinerja pelatih, namun dalam hal ini kami fokuskan pada empat faktor, dimana keterkaitan faktor faktor tersebut degan kinerja pelatih adalah:

\section{Faktor Emosional Terhadap Kinerja Pelatih}

Di tengah semakin ketatnya persaingan dalam olahraga prestasi dimana padatnya kompetisi sebagai barometer dari pencapaian prestasi dari latihan latihan yang dilaksanakan menjadikan pasang surut prestasi memberikan tekanan-tekanan kepada para pelatih dalam menjalanan tugas dan tanggungjawabnya sebagai pelatih.

Berbagai upaya telah dilakukan oleh para pelatih dalam upaya mencapai prestasi tertinggi dengan mengakomodir seluruh potensi dan sumber daya yang ada, baik yang datang dari dalam diri pelatih tersebut maupun yang berasal dari luar diri pelatih seperti dukungan orang tua, fasitas latihan, kemauan atlet dan lain sebagainya. Terkait dengan faktor yang berasal dari dalam diri pelatih tersebut salah satunya adalah kecerdasan atau kecakapan intelektual.

Kecerdasan intelektual saja tidak memberikan persiapan bagi pelatih untuk menghadapi berbagai gejolak, permasalahan kesempatan 
ataupun kesulitan kesulitan yang dihadapi dalam pelaksanaan tugas dan kewajibannya di lapangan. Dengan kecerdasan emosional, pelatih akan mampu mengetahui dan menanggapi perasaan sendiri dengan baik dan mampu membaca dan menghadapi dan merespon perasaan-perasaan orang lain dengan efektif.

Pelatih yang memiliki tingkat kecerdasan emosional yang lebih baik, dapat menjadi lebih terampil dalam menenangkan dirinya dengan cepat, lebih terampil dalam memusatkan perhatian, lebih baik dalam berhubungan dengan orang lain, lebih cakap dalam memahami orang lain khususnya para atlet di lapangan.

Dari uraian di atas dapat diambil kesimpulan bahwa kecerdasan emosional merupakan salah satu faktor yang penting yang seharusnya dimiliki oleh pelatih dalam menjalankan tugas agar memperoleh kinerja yang baik

\section{Faktor Kepemimpinan Terhadap Kinerja Pelatih}

Dalam pelaksanaan pelatihan dilapangan bagi pelatih bahwa yang terpenting adalah bagaimana menciptakan kondisi atau proses yang mengarahkan para atletnya bisa melakukan aktivitas latihan sesuai yang direncanakan dan yang diinginkannya Pelatih adalah pemimpin dalam menjalankan kepemimpinannya mempunyai cara dan gaya. Pelatih sebagai pemimpin itu mempunyai sifat, kebiasaan, temperamen, watak dan kepribadian sendiri yang khas, sehingga tingkah laku dan gayanya yang membedakan dirinya dari orang lain. 
Raph White dan Ronald Lippitt menyatakan bahwa gaya kepemimpinan adalah suatu gaya yang digunakan oleh seorang pemimpin untuk mempengaruhi bawahan. Dalam konteks kepelatihan bawahan tersebut adalah atlet.

Berpijak dari pengertian kepemimpinan sebagai suatu kegiatan untuk mempengaruhi orang lain dalam koteks mengajak, membawa, memerintahkan, mengarahkan orang lain dalam hal ini atlet tentunya untuk bisa dipengaruhi sesuai dengan tujuan atau sasran yang telah di inginkan atau ditetapkan. Jika tujuan yang diiginkan akan mempengruhi dari hasil atau kinerja dari pemimpin dalam hal ini pelatih, maka jelas bahwa kepemimpinan akan berpengaruh pada kinerja. Permasalahannya sekarang adalah bagaimana gaya kepemimpinan tersebut cocok, tepat untuk bisa mempengaruhi dalam berbagai situasi dan kondisi sehingga tujuan yang diinginkan bisa tercapai secara efektif dan efisien.

Pola dari gaya kepemimpinan pelatih juga berpengaruh dalam meningkatkan motivasi atlet dalam berlatih yang juga akan turut meningkatkan kinerja pelatih di lapangan sebagai salah satu pendorong dan memotivasi para atlet untuk terus berlatih dan berprestasi

\section{Faktor Motivasi Terhadap Kinerja Pelatih}

Motivasi adalah kesatuan hasrat atau keinginan dan tujuan yang menjadi pendorong seseorang untuk bertindak atau bertingkah laku. Motivasi merupakan sumber kekuatan bagi seseorang dalam bertindak. 
Semakin kuat dorongan tersebut, maka akan semakin intensif tindakan yang dilakukan oleh seseorang tersebut dalam upaya memenuhi keinginan atau hasrat tersebut.

Motivasi merupakan bagian yang penting dalam diri pelatih yang banyak membantu dan menentukan kinerja dari seorang pelatih. Dengan motivasi yang ada pada diri pelatih baik yang berasal dari dalam diri pelatih tersebut, maupun dorongan yang berasal dari luar diri pelatih tersebut menjadi dasar pengerak utama bagi para pelatih untuk berupaya terus memenuhi kebutuhan hasrat tersebut.

Motivasi yang kuat akan memberikan energi yang besar, dimana pelatih akan semakin berusaha utuk memusatkan seluruh potensi yang ada pada dirinya untuk bisa memenuhi keinginan tersebut yang juga nantinya akan tercermin dari berapa kuat, berapa besar usaha yang dilakukan oleh pelatih tersebut. Dan tentunya usaha yang dilakukan oleh para pelatih dalam memenuhi motivasi tersebut akan memperlihatkan juga kinerja dari pelatih sebagai hasil dari upaya untuk memenuhi kebutuhan dari hasrat, dorongan atau motivasi yang ada dalam diri pelatih.

\section{Faktor Kompetensi Diri Terhadap Kinerja Pelatih}

Kompetensi merupakan kemampuan personal dalam melakukan pekerjaannya agar mendapatkan hasil dengan baik. Kompetensi dapat berupa pengetahuan, keahlian, sikap, nilai atau karakteristik personal. kompetensi adalah bagian dari kepribadian yang mendalam dan 
melekat pada individu yang dapat memprediksi dan membedakan kinerja baik buruknya kinerja seseorang sesuai dengan kreiteria atau standar yang telah ditetapkan.

Melihat tidak semua orang memiliki kompetensi yang sama baik dalam pengetahuan, keahlian, nilai sikap dan keterampilan, hal in jugalah menjadikan bahwa kompetensi banyak mempengaruhi seseorang dalam bertindak atau menyelesaikan sebuah tuntutan tugas dan tanggungjawab yang diberikan kepadanya. Termasuk bagi para pelatih bahwa tidak semua pelatih memiliki pengetahuan, keterampilan, sikap yang sama dalam melatih, tentu hal ini akan berpengaruh terhadap kinerja pelatih tersebut di lapangan dalam rangka mencapai tujuan utamanya yaitu untuk meningkatkan prestasi yang optimal dari anak didiknya. Semua potensi yang ada pada didiknya akan diupayakan, akan dikerahkan dan akan dikembangkan yang dituangkan ke dalam unjuk kerja atau kinerja untuk bisa mewujudkan keinginan atau tujuan pelatih tersebut. 


\section{Daftar Pustaka}

Abdul Rahmat, dan Lintje Boekoesoe.2009. Kepemimpinan Gaya, Tipologi dan Praksis.Bandung. MQS Publishing.

Ahmadi, Abu. (1991). Psikologi Sosial (edisi Revisi). Semarang. Rineka Cipta

Arep, I dan Tanjung, H. 2002. Manajemen Sumberdaya Manusia. Universitas Trisakti. Jakarta.

Arikunto, Suharsimi. (1990). Prosedur Penelitian Suatu Pendekatan Praktek. Jakarta: Bina Aksara.

Ary, Donald, Lucky Cheser Jacob, Rezavich Ashghar (1982). Pengantar Penelitian dalam Pendidikan (alih bahasa Arief Furchan). Surabaya: Usaha Nasional.

Australian Coaching Council Incorporated . (1991). Better Coaching Advance coach's Manual. Australian. Australian Sports Commission.

Bompa Tudor O. 1994. Theory and Methodology of Training. IOWA; Kendal/Hunt Publishing Company

Goleman, Daniel. (2000). Emitional Intelligence (terjemahan). Jakata : PT Gramedia

(2000). Working With Emotional Intelligence (terjemahan). Jakarta: PT. Gramedia Pustaka Utama

Gomes, Faustino Cardoso, Manajemen Sumber Daya Manusia, Penerbit Andi Offset, Jakarta, Tahun 2000.

Handoko, Hani, Manajemen Personalia Dan Sumber Daya Manusia, Edisi Kedua, Penerbit BPFE-UGM, Yogyakarta. 
Harsuki (2003). Perkembangan Olahraga Terkini kajian Para Pakar. Jakarta. PT. Raja Grafindo Persada.

Husdarta. H.J.S. (2011). Manajemen Pendidikan Jasmani. Bandung. Alfabeta

IOC (2001). Olympic Solidarity, Sports Administration Manual. Laussane. IOC

John Whitmore, Coaching For Performance; seni mengarahkan untuk mendongkrak kinerja, diterjemahkan oleh Dwi Helly Purnomo dan Louis Novianto: Gramedia Pustaka Utama Jakarta. 1997

Kementerian Pemuda dan Olahraga Republik Indonesia (2010). Penyajian Data dan Informasi Statistik Keolahragaan Indonesia Tahun 2010. Jakarta Kemenpora RI

(2010). Rencana Strategis Kementerian Pemuda dan Olahraga Tahun 2010-2014 . Jakarta Kemenpora RI.

Lovelock Christoper. H. (1991) Service Marketing. USA: Prentice Hall, Inc.

Mangkunegara, Anwar Prabu, Manajemen Sumber Daya Manusia Perusahaan, Penerbit PT, Remaja Rosdakarya, Bandung, Tahun 2000 Halaman 164.

Maslow, Abraham H. (1994). Motivasi Dan Kepribadian 1, Teori Motivasi dengan Pendekatan Hiraki Kebutuhan Manusia. Bandung. LPPM \& PT. Pustaka Binaman Pressindo.

Maurice Galton dan Brian Simon, Progress and Performance in The Primary Classroom . London.1999

Nawawi, H. Hadari, Manajemen Sumber Daya Manusia, Penerbit Gajah Mada University Press, Yogyakarta, Tahun 1997.

Patricia King, Performance Planning And Appraisal: A How To Book For Manager (New York, St. Lois San Francisco: McGraw-Hill Book Company, 1993.

Pulungan, Ismail. 2001. Manajemen Mutu Terpadu. Jakarta : Universitas Terbuka.

Riduwan \& Engkos Ahmad Kuncoro (2010). Cara Menggunakan dan Memakai Path Analysis (Analisis Jalur). Bandung. Alfabeta. 
Rivai, Veithzal. 2007. Kepemimpinan dan Perilaku Organisasi. Edisi 2. PT. Raja Grafindo Persada, Jakarta.

Saphiro, Lawrence E. (1998). Mengajarkan Emotional Intelligence Pada Anak. Jakarta : Gramedia.

Satiadarma, Monty P. (2000) Dasar dasar Psikologi Olahraga. Jakarta. PT. Pustaka Sinar Harapan.

Setyo .Broto, Sudibyo. (1989) . Psikologi Olahraga. Jakarta. PT. Anem Kosong Anem.

Siagian, Sondang P. 2004. Fungsi-fungsi Manajerial. Bumi Aksara, Jakarta

Sondang P. Siagian .(2003). Teori dan Praktek Kepemimpinan (cetakan ke lima). Jakarta. Rineka Cipta.

Stoner, James. A.F, R. Edwar Freeman dan Daniel R Gilbert . 1996. Manajemen. PT. Prehallindo. Jakarta

Sudarwati, Lilik (2007). Mental Juara Modal Atlet Berprestasi. Jakarta PT. Rajagrafindo Persada.

Thanthowi, Ahmad. (1991). Psikologi Pendidikan. Bandung. Angkasa.

Thoha, Miftah. 1983. Kepemimpinan dalam Manajemen. Jakarta: Rajawali Pers.

Thoha, Miftah. 1991. Kepemimpinan dalam Manajemen. Rajawali : Jakarta.

Tim Dosen Administrasi Pendidikan Universitas Pendidikan Indonesia. (2009) . Manajemen Pendidikan. Bandung. Alfabeta

Umar, H. 2003. Riset Sumberdaya Manusia. PT Gramedia Pustaka Utama. Jakarta.

Uno, Hamzah B. (2006). Teori Motivasi dan Pengukurannya, Analisis di Bidang Pendidikan. Gorontalo. Bumi Aksara.

Uno, Hamzah B \& Lamatenggo Nina. (2012). Teori Kinerja dan Pengukurannya. Gorontalo. Bumi Aksara

W.S. Winkel. (1996). Psikologi Pegajaran. Jakarta. Grafindo 
Wahjosumidjo, (1993). Kepemimpinan dan Motivasi. Jakarta: Ghalia Indonesia.

Winardi. (1999) Motivasi dan Pemotivasian Dalam Manajemen. Jakarta. PT Raja Grafindo Persada.

Windura, Sutanto. (2008) Brain Management Series, Brain management For managing People. Jakarta. PT. Elex Media Komputindo.

Wirawan, (2003) Kapita Selekta Teori kepemimpinan Pengantar Untuk Praktek dan Peneliti Buku 1. 